\title{
Like a Prophet - On Christian Interpreta- tions of a Madonna Video
}

Throughout the history of Christianity, its relationship to art has been a complicated one, concerning the use of art in worship as well as the views on "secular" art. This article deals with a current example of the latter. More specifically, the article examines some examples of Christian views on popular music.

The best-known reactions to pop and rock music ${ }^{1}$ by Christians are likely to be negative ones, probably because these are usually the most loudly declared. But there is also another aspect to the Christian discourse on popular music. Some Christians try to emphasise what is perceived as a positive message in "secular" rock music. This part of the debate is the main concern in this paper. ${ }^{2}$

The examples used deal with one of the most controversial pop artists, Madonna, and one of her most discussed works, the video 'Like a Prayer'. Madonna Louise Ciccone, born 1958, has been one of the most successful, most imitated and certainly most talked about popular artists of the past decade. She has - at least to a certain degree quite consciously - stirred up controversy with several of her videos. Raised a Catholic, her use of religious themes and images is one aspect that has caught special attention. This is especially the case in the reactions to the video 'Like a Prayer' that was released in 1989 (cf. Andersen 1991: 198-203; Thompson 1991; Bego 1992).

The article is written from a sociological perspective. Considering the importance of popular music in the lives of many - especially young people today, the way Christianity deals with this phenomenon is an important example of how it deals with modern society. The general theoreti-

1. I use the practically indefinable terms "rock" and "pop" as meaning more or less the same thing, and in the broadest possible sense, including many diverse styles of popular music as well as different forms of extra-musical expression, e.g. videos.

2. In a forthcoming paper on a Finnish newspaper debate on Christianity and rock, I take a closer look at the negative views. 
cal framework is borrowed from Peter Berger's and Thomas Luckmann's The Social Construction of Reality (1987). Four Swedish texts on 'Like a Prayer' are analysed. The aim of the article is to show how the Christian discourse on rock, exemplified by these four texts, functions as a maintenance of the Christian world view, or symbolic universe.

\section{Theoretical Perspective}

In this passage, I present the theoretical framework of the study. First, I discuss some concepts from Berger and Luckmann (1987), then briefly the concepts of "text" and "symbol".

\section{Devaluation and incorporation}

This article is written within the framework of the sociology of knowledge presented by Berger and Luckmann (1987). Borrowing a term from Berger and Luckmann (1987: 113-115), a particular religion can be seen as a symbolic universe. The word that best describes the function of a symbolic universe is legitimation. All institutions require legitimation. They need to be explained and justified, to become plausible and meaningful to the individual (Berger and Luckmann 1987: 110).

A symbolic universe legitimates not one single institution or one single experience, but the total individual and social existence.

Symbolic universes are bodies of theoretical tradition that integrate different provinces of meaning and encompass the institutional order in a symbolic totality (Berger and Luckmann 1987: 113).

A symbolic universe is a body of cognitive as well as normative knowledge that makes the entire existence, society and individual life, a meaningful whole. Institutions which have separate origins, different contents and functions are fused into a harmonic order. The word "symbolic" implies that a symbolic universe creates order and produces meaning through references to a reality that is other than, transcends, the reality of everyday experience (Berger and Luckmann 1987: 55).

A symbolic universe claims monopoly on explaining the existence. Alternative world views, or phenomena that seem to be unexplainable in one's own terms, always raise questions. Therefore, nothing is allowed to exist that can not be explained by the symbolic universe, and no alternative explanations are accepted. In a traditional society, with only one symbolic universe, this causes relatively few problems: the symbolic universe is 
more or less taken for granted by the members of the society. But in situations where a symbolic universe is threatened by competition, which is the case in a pluralistic society, a more active defence of the monopoly becomes necessary (Berger and Luckmann 1987: 122-126).

Berger and Luckmann (1987: 130-134) mention two different types of conceptual machinery that are used to defend a symbolic universe. These they call therapy and nihilation. Therapy is directed towards individuals, actual or potential deviants, and aims at keeping these from "emigrating" from the symbolic universe. Nihilation is denying the existence of a competing symbolic universe (or universes) altogether. It is a negative legitimation, an elimination of everything that does not fit into one's reality. There are two different types of nihilation, which will here be called devaluation and incorporation. Here they are described as ideal-types, but empirically they may appear mixed.

Devaluation is granting that which does not fit into one's symbolic universe "an inferior ontological status" (Berger and Luckmann 1987: 132), degrading it to a state where it is not to be taken seriously, and therefore cannot be a threat. What is perceived as "deviant" is placed in a totally different and lower category. Devaluation can be combined with therapeutic efforts. Incorporation is an attempt to include what is outside in the symbolic universe by accounting for it in one's own terms. By translating the apparently strange or deviant into the familiar language, the threat is turned into a confirmation of the symbolic universe: deviance becomes meaningful only when it is interpreted in terms of one's own symbolic universe.

The aspect of nihilation is central to the current study of the Christian discourse on rock and pop music. Both devaluation and incorporation are evident in this discourse: calling rock "the devil's music" or "loud noise" is devaluation; arguing that Prince or Madonna are good Christians, and that their music contains a religious message, is incorporation. Even if neither type of "extreme" reactions to certain artists or rock music in general are uncommon, some try a middle course, e.g. saying that explicitly Christian rock is good and the rest is bad - and some are rather indifferent. ${ }^{3}$

The choice between devaluation and incorporation is a choice between two different attitudes towards the surrounding society. As Berger (1967: 155) puts it:

3. A discussion of the possible correlation between e.g. organisational types and attitudes towards rock - the hypothesis would be that churches are incorporating, sects devaluating and denominations indifferent - is outside the scope of this article. 
...the fundamental problem of the religious institutions is how to keep going in a milieu that no longer takes for granted their definition of reality. ...the two basic options open to them are those of accommodation and resistance to the massive impact of this milieu.

Accommodation can be understood as meaning the same as incorporation and resistance the same as devaluation. The choice is between drawing a sharp line between oneself and "the world", or trying to embrace the total "milieu".

In this paper, the emphasis is on incorporation. This same term is used by Williams (1976), and I will here briefly discuss his use of the term. His reasoning is not far from that of Berger and Luckmann (1987: 130-134), but differs in being explicitly Marxist. Williams (1976) departs from Gramsci's concept of hegemony, which he describes in a manner quite similar to how Berger and Luckmann (1987:113-115) describe a symbolic universe: as a "totality" that "saturates" society, and constitutes the limits of common sense. ${ }^{4}$

Williams (1976) emphasises that a hegemony is not a static system:

On the contrary we can only understand an effective and dominant culture if we understand the real social process on which it depends: I mean the process of incorporation.

He thus gives incorporation a central role in the maintenance of the hegemony. Williams (1976) describes incorporation as the process by which certain

...meanings and practices are reinterpreted, diluted or put into forms which support or at least do not contradict other elements within the effective dominant culture.

McHoul (1986) provides an example of how Williams' concept of incorporation can be used. She describes incorporation as a "discursive transformation" that aims at neutralising marginal or oppositional discourses. McHoul (1986) discusses policies on equal opportunity in education in Queensland, Australia. She says that these policies should not be "celebrated as the thin end of the emancipatory wedge", but understood as an attempt to neutralise radical feminism. Feminism is incorporated by patriarchal politics and turned into relatively "harmless" policies for equal

4. Williams (1976) talks about dominant culture that incorporates emergent cultures, and even if the institutional Christianity that incorporates rock is not as dominant as it once was, it partly strives to maintain some dominance, and partly tries to forget that its dominance has diminished, "continuing to voice the old totalitarian claims as if nothing had happened" (Berger and Luckmann 1987: 142). 
opportunity - and this simultaneously gives the politicians an "emancipated" image. Though it may seem farfetched, I would argue that the Christian incorporating readings - "discursive transformations" - of popular music function in a manner similar to - for example - the political incorporation of feminism into policies on equal opportunity.

\section{Text and symbol.}

One assumption central to this study is that a "text", in a broad sense, can mean different things to different people. This is also quite obviously the case in the different interpretations of the video 'Like a Prayer' discussed in this paper. What people respond to, what the participants of the religious discourse on this video commend or condemn, is their interpretation of the video, what it means to them. The video has no a priori meaning, but its meaning is shaped by the discourse (cf. Foucault 1972: 49) ${ }^{5}$.

A text - a pop song, a music video - can be interpreted, read, used in different ways. The "author" - a concept that of course is more than usually questionable in the very collective business of making popular music is one of all the users, perhaps "first among equals", but without anything resembling final authority over the meaning of the text. For example, a piece of music that in the production end has no significant meaning other than being a saleable commodity, can in its use by the members of a certain subculture become a carrier of a completely different, even explicitly anti-capitalistic message (Wicke 1990: 181-182). In the same way, a pop song that has been manufactured without any religious intent whatsoever, can by its Christian interpreters be invested with a deep religious meaning.

Some texts are more open to different interpretations - and thus more "usable" - than others. A prime example of an in this respect open text is a music video. The fast flow of often very strong images is rich in associations and can easily give rise to different interpretations. In the case of the music video this serves a concrete purpose, namely a commercial one (Wicke 1990: 162-163; Huhtamo and Lahti 1989). The place of the music video in the music business is to function as an advertisement, to promote

5. This is of course a very big subject, and one that eventually leads to major philosophical questions on the nature of knowledge, etc. May it here suffice to say that I depart from the premise that a "text" never has a most basic, truest, denotative meaning (Barthes 1970: 13-14). This, in turn, is based on the assumption that society is not made up of "social facts", existing independently of its individual inhabitants and observers, but is rather constantly created and recreated in an ongoing social process (Berger and Luckmann 1987: 78). Consequentially, the meaning of a text is no given "fact" but socially constructed. 
the artist, the album the song is taken from as well as other products associated with the artist. A good advertisement cannot be "boring". It must be able to catch the attention of the viewers, and be interesting enough to do so also after many viewings. The fast tempo as well as the eye-catching and thought-provoking images that make a video functional as an advertisement also make it open to many interpretations as a cultural text.

To conclude the theoretical considerations, I would like to summarily discuss the concept of symbol. Such a discussion, problematic as it is, can hardly be avoided, as the debate over 'Like a Prayer' is to a great extent a debate over its use of religious symbols. I will base my attempt to understand the concept on considerations partly rising from the discussion on Berger and Luckmann (1987), and partly akin to the discussion on the notion of text.

Berger and Luckmann (1987: 55) define - in effect the religious - symbol as a sign that refers to something transcendent. A religion, a symbolic universe, performs its legitimating function by referring to a transcendent reality, and the medium of legitimation is the religious symbol. As Geertz (1973: 90) puts it:

Religious symbols formulate a basic congruence between a particular style of life and a specific (if, most often, implicit) metaphysic, and in so doing sustain each with the borrowed authority of the other.

Geertz (1973) and Berger and Luckmann (1987) thus give symbols a very central position in religion, and particularly in religion's function as legitimation of the reality one lives in, that is as a symbolic universe.

An important addition to the preceding remarks on symbols is presented by Kristeva (1986). She discusses the difference between symbol and sign. Her point of departure is C.S. Peirce's well-known classification of the sign in icon, index and symbol. In the icon the connection between signifier and signified is based on analogy, in the index on causality and in the symbol on convention or "law" (Kristeva 1986; Barthes 1967: 36-38). In agreement with Berger and Luckmann (1987), Kristeva (1986) states that a symbol refers to something transcendent. She calls a symbol a "transcendental closure", while a sign is "an open-ended material structure"; a symbol retains meaning, a sign produces it. In other words: a symbol is something "god-given", but a sign is something one can understand and use (almost) as one wishes.

At the end of the Middle Ages and the beginning of the Renaissance, when art began to free itself from the church, there was, according to Kristeva (1986), a shift from a thinking based on symbol to one based on sign. 
This shift is, I think, an indication of the (beginning of the) shift from a traditional society, with one symbolic universe, to a pluralistic society. It consists of a change in the nature of the convention on which the symbol is based. In a traditional society, this convention has the nature of a dogma, more or less taken for granted as part of the symbolic universe. In a pluralistic society, with no universally accepted symbolic universe, the social nature of a convention, as an agreement between several individuals, implies that the meaning of a symbol - that Kristeva (1986) would now call sign - is open to dispute. But for those who live within one particular symbolic universe, the symbol still retains the meaning it has always had, and it cannot be understood in any other way - whether it appears in a traditional context of worship, or in a video by Madonna.

Fiske's (1989: 103-104) comments on Madonna's use of religious symbols can be viewed from the perspective outlined in the two previous paragraphs. He claims that Madonna's use of religious imagery is generally directed at freeing the use of religious symbols from the dichotomy religious/sacrilegious, to enjoy it in her own way, because she finds them beautiful. Madonna empties the symbols of their religious content, their reference to the transcendent - disconnects the signifier from the signified and converts them into pure aesthetics. The way she uses not only religious symbols in her own fashion is, according to Fiske (1989: 106), however not pure surface, not strictly an empty signifier, it carries one message: it shows that she is an independent woman.

From a religious point of view, such an independent, indifferent use of the symbols that carry one's world view can hardly be accepted. A completely neutral reaction is practically impossible. Therefore, the possible reactions are devaluation, seeing her use of religious symbols as sacrilegious, or incorporation, seeing e.g. Madonna's use of religious symbols as being within the religious tradition. In Kristeva's (1986) terms, it is clear that Madonna uses e.g. the crucifix not as a symbol, but as a sign.

\section{The Readings of 'Like a Prayer'}

The main topic of this paper is the extensive discussion of the video 'Like a Prayer' by Madonna. The emphasis is on the incorporating readings of the video, but devaluating readings will be presented as background, as will some examples of the academic discussion on 'Like a Prayer'.

The video 'Like a Prayer', directed by Mary Lambert, was released on 3 March 1989. The video opens with a scene of (the character played by) Ma- 
donna running and entering a church. There she kneels before a black statue posted behind an iron-bar door, and then lies down on a pew. There follows a dream sequence in which a scene which Madonna had witnessed before entering the church is flashbacked. A young white woman is assaulted, possibly murdered, by a white male gang, a black man comes to the woman's assistance, and is arrested by the police. In Madonna's dream the statue, played by the same actor who plays the arrested black man, comes to life, Madonna sings and dances with a black choir, dances alone with burning crosses in the background, is stigmatised and is kissed by the black man/statue. After the dream she goes to the police station to witness on behalf of the wrongly arrested black man, who is released. The video ends with a curtain call and a sign: "The End" (Madonna 1990).

Below are some of the comments on and analyses of 'Like a Prayer'. First, I present some academic views on the video, then the Christian texts that here make up the main object of study. The discussion on these is divided into three parts: the first deals with devaluating and the second with incorporating readings, and the third part discusses the Christian texts with special emphasis on the reading of religious symbols in 'Like a Prayer'.

\section{Academic studies}

Hardly any other popular artist has received as much attention from the scientific community as Madonna (cf. e.g. Schwichtenberg 1993), and 'Like a Prayer' has since its release been one of her most discussed videos also in the academic context. Here I will briefly present three different academic studies of 'Like a Prayer'. Scott (1993) emphasises race, McClary (1990) gender and Huhtamo and Lahti (1989) media.

Scott (1993) sees 'Like a Prayer' as a strong anti-racist statement. Kaplan (1990) also points out the racial theme, and sees the video as a progressive statement in a sensitive question current on the American agenda - in line with two of Madonna's earlier videos: 'Papa Don't Preach', on teenage pregnancy and abortion, and 'Open Your Heart', on pornography. Scott (1993) interprets the message of 'Like a Prayer' partly along the same lines as one of the Christian interpreters discussed later, Hansson (1990): that there is strength and courage to be found in the church. However, Scott (1993) emphasises that it is expressly in the black church that these positive powers are to be found - he does not discuss the obvious mingling of black and Catholic religious traditions in the video. He points out that to blacks, dancing in the church is no sign of disrespect, but quite the opposite, a part of the worship. He interprets the burning crosses in the most 
close-at-hand way, as symbols of the Ku Klux Klan that Madonna defies by upstaging the burning crosses in the video, as well as by finally standing up for the truth about the crime. Scott (1993) praises Madonna for presenting a positive, and as he sees it realistic, picture of the African-American community.

According to Scott (1993), the criticism of the video is due to the fact that it depicts a relationship between a black man and a white woman. He claims that the critics are preoccupied with Madonna's dress because it is seen as sexually arousing the black man in the video. He rejects the interpretation that the black statue is somehow brought to life by Madonna as an example of the interpretation of the relationship between the two main characters in the video as being primarily sexual, as an indicator of the prevailing view in white (American) society that black men can have no other than sexual interests in white women. This view originated according to Scott (1993), as the slave owners' device to make sure the white women kept their distance from the male slaves. The prime example of this view in this context is the reaction to the image of the black man kissing Madonna. Scott (1993) points out that the indignation at this scene, together with the almost automatic assumption of the erotic nature of the kiss, is closely akin to the reaction of the police, who at the beginning of the video arrest the black man for a crime (against a white woman) he did not commit. It is, in short, racist.

McClary (1990), who writes from a feminist perspective, sees the sexual aspects of the video as central, in contrast to Scott (1993), who wants to deemphasise these aspects. McClary (1990) sees the video as part of Madonna's constant invoking of the dichotomy of virgin and whore. She states that the issue that has to many critics been the big problem with the video is the combination of sex and religion, but that this is part of both the religious traditions the video draws on, the Catholic and the African-American church. McClary (1990: 15) sums up as follows:

The references to Catholic mysticism and the Black gospel church are made explicit in the visuals, with a heady mixture of a miraculous weeping statue, the stigmata, the St.Teresa-like union between the saint and the believer, andthe highly physical musical performance by the Andraé Crouch Choir. Within the security of the church, difference can be overcome and the boundless joy of music can become reality.

Thus, in McClary's reading, the patriarchal virgin/whore categorisation is overcome by the video's use of the parts of Christian tradition that affirm the physical, the sexual and thereby question the virgin/whore dichotomy. 
Huhtamo and Lahti (1989) discuss 'Like a Prayer' primarily as an advertisement for Madonna and products with her brand. The ending of the video - the curtain and the "The End"-sign - for instance, they see partly as a way of forcing the television channels to - against common practiceshow the whole video; partly as a way for Madonna to emphasise her role as an actress - a career she is most eager to pursue. The whole video reminds them of a movie trailer - for a film that does not exist. They present a few comments on the video by a group of students, showing the multiplicity of possible readings that is the direct result of the conscious use of complicated imagery for a commercial purpose

\section{Devaluating readings}

I will now turn to the discussion of the Christian reactions to 'Like a Prayer'. By far the loudest general reaction to the video on its release was negative. An indication of this is the actions of the Pepsi Cola Company. The video release was preceded by a commercial advertising Pepsi Cola. The commercial featured Madonna, was accompanied by the song 'Like a Prayer', and used pictures of Madonna dancing in a church that were similar to, but not identical with, images in the video. Pepsi was also to sponsor the release of the video and the single, and Madonna's coming tour (Andersen 1991: 198).

The fundamentalist American Family Association, headed by Reverend Donald Wildmond, called for a one-year boycott of Pepsi due to the "blatant offensiveness" of 'Like a Prayer', and was joined in this demand by the Catholic bishop of Corpus Christi, Texas. Three weeks after the release of the video, and after allegedly thousands of letters and telephone calls urging them to do so, Pepsi withdrew the advertisement that had cost them a total of $\$ 10$ million, half of which was Madonna's fee (Andersen 1991: 202203; Bego 1992: 223).

Opinions akin to the Christian devaluating comments were also expressed by several commentators outside an explicitly Christian context. In the Finnish tabloid newspaper 'Iltalehti', the video caused comments on Madonna "swinging her breasts" in the low-necked dress - and the reviewer claims the story deals with, among other things, crucifixion and resurrection. The video is said to be a sign of the maker's bad taste, but not blasphemous (Montonen 1989). Of Madonna's numerous biographers, Andersen (1991: 199) calls the passage where Madonna is kissed by the black man "orgiastic"; Thompson (1991: 140), like Ahrnroth (1991: 173), quoted below, calls the dress an undergarment, and claims that at one point it seems as if Madonna was about to "fall out of her bra". 
The religious texts on 'Like a Prayer' discussed in this paper were all written and published in Sweden within two years after the release of the video. I will first, mainly to show the contrast, discuss two devaluating readings, then two incorporating ones. Considering the very strong negative reactions to the video from different religious circles, and the critical readings by Christian and "secular" interpreters, the very positive opinions on it expressed in the incorporating readings should stand out even more clearly.

The first of the two devaluating readings is made by Ann Ekeberg, a teacher. Her passage on Madonna's 'Like a Prayer' is as follows (Ekeberg 1991: 92$)^{7}$ :

A Moslem organisation in London reacted very strongly to her video 'Like a Prayer'. They felt that Madonna had gravely blasphemed Jesus, who is a great prophet in Islam. In the video a lightly dressed and wriggling Madonna kneels singing in a church. She also shows hands that are marked by stigmatisation. Statement in Penthouse, September 1985: 'Crucifixes are sexy because there is a naked man on them.'

Thomas Ahrnroth is a journalist and writer connected to the fundamentalist "Livets Ord" congregation in Uppsala, Sweden. The following passage is from Ahrnroth (1991: 173):

In the video 'Like a Prayer' Madonna dances in underwear in front of three burning crosses, she dances in the same underwear in a church in front of a crucifix with a coloured Jesus-figure. During the song she is stigmatised, the black Jesus comes alive and takes Madonna in his arms. Madonna sings the chorus with a black choir.

- The video stirred up such strong feelings among the Catholics in the U.S.A. that Pepsi Cola, who had paid Madonna a lot of money to promote their beverage, pulled out of the deal. Madonna kept the money.

I will make a few comments on Ahrnroth's and Ekeberg's readings of 'Like a Prayer', mainly to make clearer the comparison to the incorporating readings. Striking is the superficial retelling of the content of the video. Neither of these two authors mention the main story of the video or any-

6. They are also, in all likelihood and to the best of my knowledge, all the Swedish texts on the subject published in this type of context: in Christian books and one educational video on popular music.

7. All quotes from the Swedish sources (Hansson 1990: 97-99; Ahrnroth 1991: 173; Ekeberg 1991: 92; Boström and Lundström 1990) are given in my translations of the Swedish original. The discussed passages by these authors will for the sake of readability be referred to in the text by the author's name only, without constant repetition of publishing year and page numbers. 
thing connected with the murder. It is as if they had not at all noticed the part of the video that takes place outside the church, and all the less what actually happens there. This refusal to pay proper attention to the video, to reflect on its content, in short the refusal to take it seriously, is in a sense the ultimate devaluation of the video and of Madonna. The superficiality of the reading is underlined by the fact that Ahrnroth makes two mistakes in his depiction of the elements he mentions: he repeatedly calls Madonna's dress "underwear" - admittedly not that far off - and claims she dances in front of a crucifix in the church, but no such image actually appears in the video. ${ }^{8}$

Ahrnroth and Ekeberg are both rather "matter of fact", they present a list of things that (are said to) occur in the video, and leave the rest more or less up to the reader, who in the recipient design of these books is a devout and conservative Christian. The books these passages are taken from, especially Ekeberg (1991), are to a large extent made up of such lists. Immense amounts of not always very accurate details, the sum of which is expected to have an effect, are hammered into the reader. An added instrument is the juxtaposition of sentences, e.g. the last two sentences in the quote from Ekeberg, where the in principle irrelevant quote from Penthouse serves to convince the readers of the insincere, and hence blasphemous, use of the stigmatisation image in the video.

The elements mentioned in both quotes - the dress, the dancing, the stigmatisation, as well as Ahrnroth's repeated mentioning of the crosses, and the way these are juxtaposed - suggest that what these authors react most strongly to is the combination of sexuality and religion. The passage from Ekeberg is immediately preceded by the following sentence (Ekeberg 1991: 92):

Madonna is a rather mediocre singer, but she manufactures porn-rock and provokes with a mixture of religion and sex.

What these white, Scandinavian and Protestant authors react to is not primarily the relationship between a black man and a white woman but

8. The errors and the general superficiality of the comments almost lead one to question whether these authors have actually seen the video. This would be rather a grave accusation, and I am only suggesting the possibility. But the fact is that Ahrnroth (1991, 172-175) bases his two-page discussion of the documentary 'In Bed with Madonna' entirely on newspaper clippings; and he claims the video 'True Blue' shows Madonna as a striptease dancer with a whip, wearing sado-masochistic leather underwear, and that a small boy watches her show. The video he is probably refering to is 'Open Your Heart', where Madonna dances - without whip and not wearing anything that looks like leather - in a peep show, and the boy is not admitted. (Madonna 1990) 
how this woman is dressed and how she behaves in church. In other words, they would agree with McClary (1990) that Madonna's negligence of - attempt to abridge - the virgin/whore dichotomy is central to the video, but strongly disagree on the value of this message.

\section{Incorporating readings}

In this section of the article, two Christian interpretations of 'Like a Prayer' that can both be characterised as incorporation are discussed. One is from Hansson (1990), the other from Boström and Lundström (1990).

Mikael Hansson is a pastor in the church of Sweden, and his book (Hansson 1990) was published by the church of Sweden as part of a project called "Svenska kyrkans bekännelsearbete". The aim of the project was to discuss the position, identity and beliefs of the church of Sweden in current society (Gerhardsson and Persson 1985: 5-6). The context in which Hansson (1990) was published thus gives the book something of an "official" status.

The contrast between the readings of 'Like a Prayer' by Ahrnroth and Ekeberg and the interpretation made by Hansson (1990: 97-99) is striking. Hansson describes the video at length and is very positive towards what he perceives as its religious content. The fact that he, as well as Boström and Lundström (1990), select 'Like a Prayer' for special attention (Hansson's discussion on the video takes up more than four fifths of the space he devotes to Madonna) shows that an attempt is also made to incorporate not only the video but also the artist herself — an attempt that would have had much less chance of success had the subject of analysis been almost any other video by Madonna.

Hansson begins his discussion of 'Like a Prayer' by mentioning a text on the cover of the album with the same name, where Madonna thanks her mother for teaching her to pray. He also mentions that one song on the album, 'Act of Contrition', is based on the confession of sins. About the lyrics to the song 'Like a Prayer' Hansson says:

The lyrics themselves are not that remarkable. Madonna sings of someone by whom she is strongly touched and maybe it is precisely an answer to a prayer, "like a prayer", that she has met this [person]. But combined with the pictures of the video the lyrics shine with an immense religious clarity.

In the assumption that "perhaps" the title alludes to an answer to a prayer, Hansson already shows his willingness to interpret Madonna to make her

9. Translates roughly as "The confessional work of the Swedish Church". 
fit into traditional Christianity. His statement that the lyrics "shine with an immense religious clarity" in combination with the pictures of the video in all likelihood refers most directly to the black man in the video - considered by the Christian commentators discussed in this article to portray Christ - who is thought to be the person Madonna has been touched by. This "touch" is the occurrence Hansson finds to be the main subject matter of the lyrics, and he clearly, as he states that it possibly is an answer to a prayer, interprets the meeting between Madonna and the black man in an altogether different manner from e.g. the critics Scott (1993) refers to.

Hansson finds the video very clear and he states that it is "very consciously made". Even if he does conclude that his interpretation is merely the one "closest at hand", thus not the only possible one, in view of the content of the video itself, and all the different readings of it, his certainty is rather astounding.

The contrast between the street and the church, in atmosphere, colours, lighting and material, is according to Hansson a key to the interpretation of the video.

The scenes from the back street are filmed in grey hues, almost black and white. ... Inside the chapel everything is in another tone. The scenes are here in colour and the nuances are very warm and pleasant. The light is a shimmering yellow and produces the feeling that the room is lit by burning candles. Instead of cold concrete, here is warm wood. Instead of contempt and anger, here is joy and happiness.

This contrast has been pointed out in other readings as well, and is also quite clear in the video. Hansson thinks that the video depicts the Christian faith, as it is to be found in the church, as a source of power to oppose the evils that "govern our streets". While Scott (1993) finds that the video shows this power as present in the black church and the black community, Hansson makes an effort to generalise this message by claiming that the chapel in the video is

...not at all unlike the chapels and mission-halls in villages all over Sweden.

He also, of course, mentions the fact that when Madonna steps over the threshold into the church, she sings the line 'and it feels like home'.

The home that is there in the chapel where the warmth overflows her.

Hansson repeatedly mentions the church and emphasises its importance, and also compares the church in the video to churches in Sweden. He thus - in contrast with the Swedish pastor whose comments are discussed below - incorporates the video explicitly into the church, and not merely in 
general into the Christian tradition. One likely reason why he makes this rather explicit effort is the official church context in which Hansson (1990) was published.

The images in 'Like a Prayer' that have upset many Christian viewers, the dress, the dance and the kiss, are also mentioned by Hansson (1990), but in an indirect way. He states that some people felt

...she was too vulgar in her joyful dance in the chapel. The shoulder-straps keep slipping off her shoulders, the dress is ever so low-necked and shows too much of the breasts. In addition, she kisses the black Jesus a little too long and with too open a mouth for it to be acceptable. Many circles and several churches protested heavily against the sexual image Madonna has given her story.

Thus, Hansson mentions these elements only as examples of what has been criticised in the video. In a sense, Hansson denies that he himself has seen these images in the video, and writes of them almost as inventions of the critics. The tone in which he describes the criticism of the video is clearly ironic; he is mildly poking fun at those who were disturbed by the low neck, etc. He is making it very clear that he does not belong to those who "protest heavily".

Moreover, he mentions that the video was released at about the same time as Salman Rushdie's The Satanic Verses, and that some of the strongest criticism against 'Like a Prayer' came not from Christians but from Moslems.

When Madonna's video 'Like a Prayer' was released, she was also threatened with murder by Moslems. Some Moslems felt that Madonna's depiction of the saint character was blasphemous.

By making this connection between Madonna and Rushdie, Hansson - in contrast with Ekeberg, who seems to be sympathetic with the Moslem fundamentalists' feelings on blasphemy - draws a very sharp line between himself and those who do not appreciate 'Like a Prayer'.

No distinction is made by Hansson - or any of the religious authors quoted, between Madonna herself and the character she portrays in the video. Throughout his discussion Hansson refers to the main female character in the video as Madonna; there are nine direct mentions of "Madonna" as the person who enters the chapel, has wounds in her hands, etc., but not once does Hansson point to the fact that she is only portraying a character, playing a role. As a result of this, the artist herself, and not only the video, is made the object of incorporation. 
Hansson gives a fairly detailed and accurate, but not complete, account of the content of the video. One of the most eye-catching of the elements that Hansson does not refer to is the ending of the video: the red theatre curtain, the curtain call and the "The End" sign. One possible interpretation of these images is the commercial one that Huhtamo and Lahti (1989) present. But these elements have a clear origin and a conventional use: they normally function to point out that the previous occurrences have been a show, a fiction that is now over. In this video they serve as a kind of rather tongue-in-cheek "Verfremdungseffekt", and underline the distinction between the real-life Madonna and the character she portrays in the videoa distinction that e.g. Hansson does not make.

Hansson sums up his interpretation:

The interpretation of the video that is closest at hand is that Madonna wants to show that even if racism, hatred and violence govern our streets, there are forces that actively want to confront this evil and instead spread goodness. This force is enclosed in the Christian faith, it can be found in the church, it is self-giving but by no means an easy way to go for those who want to follow it. The wounds in Madonna's hands and the captivity of the saint/Jesus show that suffering and pain can be the consequence for those who want to walk the road of love in this evil world.

According to Hansson the video has a clear message, behind which he furthermore sees Madonna's own intentions. He says that her motive behind the video is to say that one, perhaps the only, source of power to fight the evil in this world is the Christian faith, or more specifically the faith of the church, including the church that is to be found "in villages all over Sweden". He claims that Madonna is siding with the good, with the church, and that this is shown on the one hand in the story of the video, where she - the character in the video, which is not distinguished from the individual or the artist - goes to the police to tell the truth, on the other hand in the fact that she, as Hansson sees it, uses her video to convey a positive Christian message, to, as he puts it, "give evidence as to what her faith means". He further makes a connection between Madonna's siding with the good, walking "the road of love", and the stigmatisation: she has received these wounds as a sign of the suffering that can be the result of choosing the side of the good.

At the end of his discussion on Madonna and 'Like a Prayer' Hansson produces the following quote from a spokesman for Madonna:

Madonna does absolutely not want to blaspheme; why, she is herself a believer and a Catholic. Quite simply the current video is a story of the battle between good and evil, and of course she is on the side of the good. 
Hansson lets this quote stand for itself, without further comments, as the final conclusion of his Madonna discussion. He thereby makes it quite clear that he fully agrees with what the press agent says, and makes this statement his own. ${ }^{10}$ Concluding the discussion with a quote from a presumably authoritative source is a way of saying "is this not exactly what I told you, now do you believe me?".

The cover of Hansson (1990) is a collage of three pictures. In the lower left hand corner is a black and white photo of Bono, the lead singer of the popular group U2 that is also discussed in the book. The upper right hand corner is a detail from the print 'Isaiah's Vision' by Gustav Doré (Familjebibel 1957: 985), and shows the prophet Isaiah. Between these pictures, and covering about two thirds of the page, is a colour photo of $\mathrm{Ma}$ donna. This picture is taken from the scene in 'Like a Prayer' where she is first kneeling down at the statue to pray. Across the page, so to say on Madonna's neck, just above the cross that clearly shows, is written the title of the book. The title translates 'God's Prophets?', with the subtitle 'On Faith and Spiritual Longing in Popular Culture'. With the title, Hansson asks if there are not prophets of God among the pop artists of today; with the combination of the title and the pictures he makes the suggestion that Madonna - in addition to being a good Christian, is one, and perhaps even one of the most prominent, of these prophets.

'Like a Prayer' is also discussed on a Swedish-produced educational video (Boström and Lundström 1990a) on Christianity and rock music. As well as a supplement booklet (Boström and Lundström 1990b). The opening images of 'Like a Prayer' are used to set off the Swedish video, with the church in 'Like a Prayer' as a background for the subtitle of the film, which translates "a film about God in rock music". This functions in a manner similar to the cover of Hansson 1990: by combining the text with the image from 'Like a Prayer', the producers of the video claim that Madonna's video is a prime example of a work of popular music, where God appears - a claim that is emphasised by the fact that the image used is an external shot of the church. In the video, a few clips from 'Like a Prayer' are shown, notably, the stigmata twice, and comments are made by one minister, two members of the "secular" Swedish pop group Lolita Pop, and by three anonymous, presumably Christian, young men.

10. Theoretically, he could of course also have quoted e.g. Madonna's anticipation of Nancy Reagan's, or Moral Majority leader Jerry Falwell's reaction to the video: "Gee, I wonder what Nancy Reagan will think of this" (Andersen 1991: 200). Or he might have mentioned the title of Madonna's video collection and best of-album, "The Immaculate Collection", a word-play on the immaculate conception. 
Here I will quote the comments the Swedish Lutheran pastor and musician Per Harling makes on 'Like a Prayer' in Boström and Lundström $(1990 a)^{11}$. He begins:

It is you know extremely biblically rich in images. You have the Christ figure, of course, and how the love from her then for this Christ figure eventually liberates him. He is then partly locked up in the churches, I suppose her message is, partly he is outside the churches.

Harling sanctions Madonna's use of religious symbols by calling the video's imagery "biblically rich". There is no trace of accusation of blasphemy in such a statement. He takes it for granted that the black man is Christ, as does one of the youths and one of the musicians interviewed in the video, and subscribes to the same view as Hansson that Christ is both the statue and the arrested black man. Between Harling's statements an inserted short comment by Steen Boberg from Lolita Pop, saying 'Like a Prayer' reminds him of the story of the Good Samaritan, further anchors Madonna's video in Christian tradition.

\section{Interpreting symbols}

This third passage of my discussion on the Christian readings of 'Like a Prayer' deals with the interpretations of some of the religious symbols in the video. Its use of symbols is an important reason why 'Like a Prayer' has attracted so much attention, and the interpretations of these symbols is an important part of the discursive transformations of the video that make up its incorporation or devaluation.

Hansson writes:

[Madonna's] imagery and her use of religious symbols is unconventional and challenging and shows that she is well acquainted with the Christian symbolic language.

Madonna's critics have not accepted what Hansson sees as her challenge. What he calls her "unconventional" use of religious symbols has been one major reason she has received such strong criticism. Her use of some of the strongest and most central Christian images and the way she combines these with her own sexual image has been seen as provocative, blasphemous, an abuse. I will in the following discuss the interpretations of three

11. In my translated rendering of Harling's oral statements I have attempted to reproduce his use of words as faithfully as possible, but I have decided not to follow strict transcription procedures, because the original utterance was in another language, and because the restricted analysis produced in this paper does not require such procedures. 
different images in 'Like a Prayer': the black statue, the stigmatisation and the burning crosses.

The first of these images, the statue, is identified by the director of the video Mary Lambert (quoted in McClary 1990: 21) as portraying St.Martin de Porres. This was a black Dominican lay-brother who lived in Peru 15791639, was canonised in 1962, and is the patron saint of race relations (Farmer 1987: 362). But the statue is automatically assumed by most commentators to represent a black Christ, and Ahrnroth goes so far as to turn the statue into a crucifix. Going along with Lambert, whose opinion of the identity of the statue none of the Christian interpreters seem to have sought, would, perhaps especially to the Protestant interpreters, mean a less "sacred" reading than seeing the statue as a portrait of Christ, and thus dilute the incorporation or devaluation respectively.

Hansson does not quite make up his mind what the statue represents; he alternates between calling it a saint, a black Jesus, and compromising with "the saint/Jesus". The instances where the label "saint" is used on its own are when Hansson explicitly talks about the statue before it comes alive, and when he refers to the Moslem reaction to Madonna's depiction of the "saint character". Referring to the statue as Jesus in that context would give more credibility to the accusation of blasphemy. The name Jesus is used on its own when Hansson refers to the living statue, and in the sequence, partly quoted below, where Hansson points out the connection between the statue and the arrested black man, which are played by the same actor.

A significant feature in the statue is of course its colour. Scott (1993), as well as Kaplan (1990), point out the importance of the racial theme in 'Like a Prayer'. To the makers of the video, too, the racial aspect seems to be central, considering the fact that St. Martin de Porres is patron of race relations, and that Madonna originally wanted the video to show a story of a black man and a white woman being chased and eventually shot by the Ku Klux Klan (Andersen 1991: 199). The unorthodox presentation of "Christ" as black has been (Scott 1993) one reason for the criticism of the video.

In contrast with - and opposition to - those who find the video's depiction of "Christ" unorthodox or even blasphemous, Boström and Lundström (1990b) explicitly state that the video gives a classic picture of Christ:

It is thus the classic picture of Christ as the helper as well as the one who gets helped that is depicted.

Boström and Lundström (1990b), as well as Hansson and Harling, produce their incorporating readings as a counter-weight to the use of (what is per- 
ceived by the Christian interpreters as) the central Christian symbol, the son of God, as an anti-racist statement. When the black race and allegedly sexual behaviour of "the Christ-figure" are seen as unorthodox and idiosyncratic, these Christian interpreters produce their traditional Christian readings of the symbol to reclaim it to its more traditional religious meaning.

The second example, the stigmatisation, is one of the strongest religious images in the video. All the writers discussed in this article refer to it, including Ekeberg, who does not even mention the statue. The devaluating readings merely mention the stigmatisation, as an element alongside $\mathrm{Ma}$ donna's vulgar dancing and dress, and let their readers draw the conclusion that such a combination cannot be proper. A reading that emphasises the provocative, and therefore commercial, aspect of the use of this image is to my mind also quite plausible. The stigmatisation is perhaps the best example in 'Like a Prayer' of an "empty" image, one that is used without religious intent by the makers of the video, but rather with a solely commercial intention.

Hansson (1990), however, insists on giving the image a traditional Christian interpretation:

When the Jesus figure is gone Madonna picks up a knife the man has held in his hand, she hurts herself on it and when she looks at her hands she notices that she has been stigmatised, she has got the marks of Jesus' wounds on her hands. It is as if she has joined in his suffering and shared the pain with him. She then understands the connection between the Jesus-statue that has come alive and the wrongly arrested black man. She understands that they are one and the same person.

He thus reads the stigmatisation in a traditional Christian manner, as a sign of participation in Christ's passion. Hansson also sees the stigmatisation as a means of a new insight by Madonna, it makes her see that the wrongly arrested man is Jesus. In his summing up, Hansson makes the stigmata central to the understanding of the whole video, saying that they show how Madonna suffered as a result of choosing to side with the good. .

Harling (Boström and Lundström 1990a) makes an innovative reading of the stigmatisation sequence:

And then they have the stigmatisation you know, with this sword, which why the sword is also an old Christian symbol, the double-edged sword that is the symbol for the word of God then, and through the word of God she gets the same kind of marks that Christ got on the cross.

He does not make the same kind of comments on the meaning of the stigmata as Hansson, but he makes his own contribution to a traditional 
Christian reading of the images. The sword that Hansson, perhaps more accurately, calls a knife, otherwise seems a bit out of place. Thompson (1991: 140), for instance, strangely enough interprets it as the weapon used in the murder outside the church. But Harling gives it a traditional Christian meaning as a symbol for the word of God (therefore he must elect the term "sword" for the weapon) that somehow gives Madonna the wounds of Christ.

The third example, the burning crosses, can readily be understood as the symbols of the Ku Klux Klan, especially considering the prominence of the race relation theme in the video. Ahrnroth, however, apparently sees the burning crosses primarily as a Christian symbol, when he refers to them alongside the crucifix as mere backdrops to Madonna's dance. Harling also comments on the crosses:

[Madonna] is consciously playing with images and symbols that are confronted with each other all the time, that seem to be each other's opposites. Take the burning cross then, which you know is if I remember correctly an old Christian symbol for God's love, that's the fire of the Spirit that is joined together with the cross, but then that has then been distorted in our own history through Ku Klux Klan you know and they have taken that as their symbol, which then has become an an an evil symbol you know.

He thus explicitly calls attention to the ambiguousness of the symbols in the video, and points out that the burning cross now functions as a symbol of the Ku Klux Klan. But he still sees the traditional Christian meaning ${ }^{12}$ of the symbol as primary, something that the Klan has taken over and corrupted, and he rather hesitates before using the adjective "evil". By identifying the fire with the Holy Spirit, Harling further connects the burning cross with the Christian symbolic universe.

\section{Conclusions}

In this article, I have discussed a case of the Christian debate on popular music, and attempted to analyse this debate from the perspective of the sociology of knowledge represented by Peter Berger and Thomas Luckmann. From this perspective, the two distinctly different approaches to the example discussed, Madonna's video 'Like a Prayer', can be understood as two means to achieve the same goal: the nihilation of any reality outside the reach of the explaining powers of one's symbolic universe.

12. Mary Lambert (quoted in McClary 1990: 15) claims that apart from referring to the $\mathrm{Ku}$ Klux Klan, the burning cross is a symbol of God's wrath. 
The emphasis in this paper has been on incorporation, here represented by the Christian readings that find a Christian content in the Madonna video. The term implies that the readings serve as an attempt to make, in this case, 'Like a Prayer' part of the Christian symbolic universe, an affirmation of the Christian faith.

Of special importance in the Christian interpretations of 'Like a Prayer' is the reading - partly against the explicit intent of the makers of the video - of the symbolic images in the video in a traditional Christian way. The devaluating critics, Ahrnroth and Ekeberg, have reacted against what they perceive as Madonna's sacrilegious (ab)use of these symbols. The incorporating interpreters, Hansson and Harling, completely turn this around: instead of seeing Madonna's use of Christian symbols as a threat, they see it as a confirmation that these symbols are strong enough not just to survive Madonna's unconventional treatment but to receive a new life as a result of it.

The incorporating readings of Madonna have different functions, partly depending on the audience. To people outside the church, they function as an attempt to enhance the image of Christianity and the church: by showing that there are Christians - ministers, even - who enjoy popular music, and by declaring that one popular artist is actually Christian. To believers, these interpretations serve as a "guide" to 'Like a Prayer' - much needed because of the multitude of religious symbols in a strange context. With this "guide", an otherwise potentially quite problematic video and artist are rendered meaningful from a Christian perspective. And by their interpretations of 'Like a Prayer', Hansson and Harling are using Madonna's video as a vehicle for conveying their own religious messages. They are attempting on the one hand to give the Christian message and the church a modern image; on the other to neutralise popular music, to take away its independence - to incorporate it into institutional Christianity.

\section{References Cited:}

\section{Ahrnroth, Thomas}

1991 Dina harpors buller. Uppsala: Trons Värld Ordbild.

Andersen, Christopher

1991 Madonna, Unauthorized. London: Michael Joseph.

Barthes, Roland

1970: $S / Z$. Lund: Bo Cavefors.

1977 Elements of Semiology. New York: Hill and Wang. 


\section{Bego, Mark}

1992 Madonna: Blonde Ambition. New York: Harmony.

Berger, Peter $\mathbf{L}$.

1967 The Social Reality of Religion. London: Faber and Faber.

Berger, Peter L., and Thomas Luckmann

1987 The Social Construction of Reality: A Treatise in the Sociology of Knowledge . Harmondsworth: Penguin. [1966]

Boström, Ulf, and Åke Lundström

1990a Rock Själ \& Ande - en film om Gud i rockmusiken. Umeå: Eikon. (Video)

1990b Rock Själ \& Ande. Umeå: Eikon. (Booklet)

Ekeberg, Ann

1991 För Sverige - på tiden: En exposé över ungdomskulturen. Bromma: Ny solidaritet.

Farmer, David Hugh

1987 The Oxford Dictionary of Saints. Oxford: Oxford University Press.

Fiske, John

1989 Reading the Popular. Boston: Unwin Hyman.

Foucault, Michel

1972 The Archeology of Knowledge. New York: Pantheon.

\section{Geertz, Clifford}

1973 The Interpretation of Cultures. Selected Essays. New York: Basic Books.

Gerhardsson, Birger, and Per Erik Persson

1985 Kyrkans bekännelsefråga. Malmö: Liber.

Hansson, Mikael

1990 Guds profeter? Om tro och andlig längtan i populärkulturen. Stockholm: Verbum.

Huhtamo, Erkki, and Martti Lahti

1989 Musta Madonna: Musiikki, rotu, kulutusjärjestelmä. Filmihullu 1989/4: 25-29.

Familjebibel

1957 Illustrerad familjebibel. Stockholm: Harriers.

Kaplan, E. Ann

1990 Modernismi, feminismi, postmodernismi, postfeminismi. Haastateltavana E. Ann Kaplan. Lähikuva 1989/4 -1990/1: 41-50.

Kristeva, Julia

1986 From Symbol to Sign. In: Toril Moi ed.): The Kristeva Reader; pp. 6273. Oxford: Blackwell.

Madonna

1990 The Immaculate Collection [video]. New York: SireWarner Bros.

McClary, Susan

1990 Living to tell: Madonna's Resurrection of the Fleshly. Genders 1990: 1-21.

McHoule, A. W.

1986 Writing, Sexism and Schooling: A Discourse-Analytic Investigation of Some Recent Documents on Sexism and Education in Queensland. In: 
Sue Fisher and Alexandra Dundas Todd (eds): Discourse and Institutional Authority: Medicine, Education, and Law, 187-202. Norwood: Ablex.

Montonen, Mikko

1989 Madonna nosti ennätyskohon - Pepsi-mainosta ei nähdä Suomessa. Iltalehti 9.3.1989: 16-17.

Scott, Ronald B.

1993 Images of Race \& Religion in Madonna's Video 'Like a Prayer': Prayer \& Praise. In: Cathy Shwichtenberg (ed.): The Madonna Connection. Representational Politics, Subcultural Identities, and Cultural Theory; 57-77. Boulder: Westview.

Schwichtenberg, Cathy (ed.)

1993 The Madonna Connection: Representational Politics, Subcultural Identities and Cultural Theory . Boulder: Westview.

Thompson, Douglas

1991 Madonna: Den ocensurerade biografin. Falun: Wahlströms.

Wicke, Peter

1990 Rock Music. Culture, Aesthetics and Sociology. Cambridge: Cambridge University Press.

Williams, Raymond

1976 Base and superstructure in Marxist cultural theory. In: Roger Dale, Geoff Esland and Madeleine MacDonald (eds): Schooling and Capitalism: A Sociological Reader; pp. 202-210. London: Routledge \& Kegan Paul. 